ROCZNIKI HUMANISTYCZNE

Tom LXIX, zeszyt 3 - 2021

DOI: http://doi.org/10.18290/rh21693-2

MIESZEK JAGIEŁŁO

\title{
HERMES TRISMEGISTOS WEDŁUG MARSILIA FICINA. ARGUMENTUM - PRZEKŁAD I KOMENTARZ
}

Zanim manuskrypt traktatów hermetycznych w 1460 r. trafił z Macedonii do Florencji, nauki i postać Hermesa Trismegistosa należały w ówczesnej Europie do zapomnianych. Zachowało się zaledwie kilka pojedynczych źródeł antycznych o tej postaci, które jednak nie dawały wystarczająco wyraźnego obrazu doktryn hermetycznych. Tłumaczeniem przybyłego z Macedonii manuskryptu zajął się Marsilio Ficino. Szybko stało się ono we Florencji i pozostałej Europie podstawowym źródłem wiedzy hermetycznej. Przedtem po Europie krążyło zaledwie dzieło pod tytułem Asclepius, którego przekład na łacinę przypisywano Apulejuszowi z Madaury ${ }^{1}$. Za pośrednictwem tłumaczeń na język arabski na Półwyspie Iberyjskim rozprzestrzeniła się jeszcze wiedza hermetyczna pochodząca z tzw. Tablicy Szmaragdowej, którą z arabskiego przełożono na łacinę w XII wieku; autorem jednego z tłumaczeń tej Tablicy na

Mgr MiesZer JAGIEŁŁo - doktorant na Wydziale Filologii Polskiej i Klasycznej UAM; e-mail: mj17669@amu.edu.pl; ORCID: https://orcid.org/0000-0003-1536-3990.

${ }^{1}$ Polski czytelnik miał dotychczas okazję zapoznać się z naukami hermetyzmu poprzez przekłady traktatów hermetycznych z greki na łacinę autorstwa Wincentego Myszora (Poimandres 205-216; Corpus IV 186-196; Corpus VI 241-247; Corpus XIII 245-256) oraz przekład Asklepiusza, dokonanego przez Kazimierza Pawłowskiego (Apulejusz z Madaury). Ponadto powstały monografie autorstwa Tadeusza Zielińskiego (Hermes), Romana Bugaja (Hermetyzm), Kazimierza Banka (W kręgu) i Agaty Sowińskiej (Hermetica), przybliżające zagadnienia hermetyczne. Powstało również niewiele artykułów traktujących o hermetyzmie, rozproszonych w czasie i pracowniach wydawniczych, np. autorstwa Liliany Nawrot (Źródta 179-199), Jana Czerkawskiego (Hermetyzm 153-169), Janusza Sytnika-Cztwertyńskiego (Hermetyzm 151-167) i Ewy Śnieżyńskiej-Stolot (Nereidy 275-287); kilka ciekawych artykułów pojawiło się również w tomie pod redakcją Roberta Ptaszka i Diany Sobieraj z 2013 r. i poświęconemu ezoteryzmowi (Ezoteryczne tropy). W Internecie powstała amatorska strona dedykowana hermetyzmowi Hermetyk pod adresem www.hermetyk.pl (dostęp 23.12.2019). Tam znajduje się też wydane nie według naukowych standardów tłumaczenie Korpusu autorstwa Rafała Wąsowskiego. Inny taki przekład (za pośrednictwem tłumaczeń na język angielski) został dokonany przez Jerzego Wadolowskiego. 
język łaciński był żyjący w XII wieku Hugo z Santalli². Jej treść w świecie arabskim była znana już od VIII-wiecznej Kitab sirr al-haliqi autorstwa Balinasa, a za sprawą jego autorytetu znalazła się potem również w Kitab Ustuqus al-Uss al-Thani Jabbira ibn Hayynana oraz w XIII wieku w Kitab Sirr al-Asrar (MacDonald 80; Ebeling 49). XIII wiek przyniósł też łacińskie tłumaczenie arabskiego grimoire pt. Ghayat al-Hakim, którego oryginalny tytuł przełożyć należałoby jako „Cel Mędrca”, a jednak zostało ono rozsławione pod tajemniczą nazwą Picatrix ${ }^{3}$. Tych tradycji hermetycznych, które pochodziły z arabskich bibliotek, Marsilio Ficino mógł nie znać. Niemniej jednak istniała również tradycja europejska, od wieków studiowanych Ojców Kościoła, do których Marsilio Ficino odwołuje się w Argumentum. W tym wstępie do swojego przekładu greckich traktatów hermetycznych pisze on o Augustynie i o Laktancjuszu. Argumentum jest utrzymane w formie krótkiego listu, dedykowanego zleceniodawcy Ficina, Kosmie Medyceuszowi. Ficino streścił $\mathrm{w}$ nim ówczesną wiedzę o hermetyzmie, przedstawił treść greckiego dzieła (później nazywanego Korpusem Hermetycznym) oraz pozdrawiał Kosmę. Z dzisiejszej perspektywy tylko ten pierwszy zakres tematyczny treści listu stanowi o wartości tegoż słowa wstępnego. Korpus Hermetyczny zachował się bowiem w oryginale greckim, który jest częściej wykorzystywany do przekładów na języki nowożytnie aniżeli łacińska, wtórna wersja Ficina. Pomimo że praca Ficina była głównym impulsem rozprzestrzenienia się hermetyzmu na terenie Europy, przekład ten został sporządzony pośpiesznie; nie był przewidziany do publikacji, a jednak został wydrukowany, bez autoryzacji i bez uwzględnienia odręcznych uwag autora przekładu, które do dziś zachowały się na jednym z manuskryptów. Wielokrotnie wznawiane edycje łacińskiego Corpus Hermeticum świadczą o dużej popularności dzieła, które jednak ze względu na niedoskonałość wydawanego tłumaczenia nie oddaje prawdziwych treści hermetycznych. Kosma Medyceusz otrzymał thumaczenie jeszcze w 1463 r., na rok przed śmiercią ${ }^{4}$.

\footnotetext{
${ }^{2}$ W tym samym stuleciu Robert z Chester skończył łaciński przekład z języka arabskiego tzw. Liber de compositione alchemie autorstwa bizantyjskiego mnicha Mariana z Rzymu (Morienus Romanus); treść tego dzieła Robert z Chester opatrzył wstępem pt. De tribus Mercuriis, który rozpowszechnił się również jako przedmowa do innych dzieł, mianowicie do przełożonego na łacinę z języka arabskiego Tractatus aureus de lapidis physici secreto (niekiedy Septem tractatus Hermetis sapientia Triplicis) oraz do Liber sex rerum principiis. W nim przekształca on nieco znaną dotychczas w świecie arabskim postać Hermesa Trismegistosa (Campanelli XXVI-XXVII).

${ }^{3}$ Zob. opracowanie krakowskiego egzemplarza Picatrix przez Ewę Śnieżyńską-Stolot (Picatrix).

${ }^{4}$ Campanelli w potężnym wstępie od swojej edycji łacińskiego Korpusu Ficina objaśnia bardzo wnikliwie kompozycję i stan tekstu, trudności redakcyjne oraz historię manuskryptów (Campanelli XXIII-CCLV).
} 
Wiedza Ficina o Hermesie pochodziła od Augstyna z Hippony, Laktancjusza oraz Cycerona. $Z$ pewnością zapoznał się też z Asclepiusem; na jednym z manuskryptów tego dzieła odręcznie zapisał krótką notatkę na podstawie cytatu z De vita et moribus philosophorum autorstwa Waltera Burleigha. Ten cytat brzmi: „Hermes Egipcius, qui et Trismegistus sive Mercurius dicitur, Platonis discipulus fuit" (Campanelli XXVIII-XXIX; 54) ${ }^{5}$. Niepewne, lecz wyobrażalne, jest to, że Ficino - choć wolał się na niego nie powoływać - znał także pisma Klemensa Aleksandryjskiego. Ficino ponadto mógł też już podczas pracy nad Korpusem (pośrednio lub bezpośrednio) mieć wiedzę pochodzącą z pseudohermetycznego zbioru aforyzmów teologicznych pt. Liber XXIV Philosophorum, który cieszył się wówczas popularnością (Trzcińska 93). Wątpliwości z kolei nie podlega fakt jego znajomości dzieł Platona, w których Ateńczyk opisuje zwyczaje Egipcjan. Ze względu na odniesienia Ficina do wcześniejszych dzieł nawiązujących do Hermesa Trismegistosa powstała konieczność poprzedzenia przekładu Argumentum krótkim wstępem na ich temat.

Przekład Argumentum został dokonany na podstawie edycji tekstu za Maurizio Campanellim (3-6). Lekkie pióro i elokwencję Ficina czuć nawet w tym krótkim piśmie; należy jednak podkreślić głębokie oburzenie Campanellego nad stanem różnych edycji przekładów Ficina, począwszy od pierwszego wydania z 1471 r., a kończąc na krakowskim wydaniu szesnastym z 1585 r., opatrzonym rozległym komentarzem Hannibala Rosellego, które współczesny redaktor tego tekstu wnikliwie omawia (Campanelli LXILXIX). Niniejsze tłumaczenie Argumentum zostało opatrzone przypisami objaśniającymi jego treść oraz oryginalny tekst łaciński. W akapitach poprzedzających przekład zostały umieszczone fragmenty z dzieł stanowiących źródła wiedzy Ficina; ograniczono się jednak do wyłącznie tych tekstów, które dla autora Argumentum stanowiły najważniejszą inspirację. ${ }^{6}$

\footnotetext{
${ }^{5}$ „Hermes Egipcjanin, który nazywany jest też Trismegistos albo Merkury, był uczniem Platona.” Tłum. M.J.

${ }^{6}$ Por. Campanelli XXIII-LX. Pośród dzieł antycznych, które być może nawiązują do tradycji o Hermesie Trismegistosie, można jeszcze wymienić O Izydzie i Ozyrysie Plutarcha (Plut. De Is. et Os. 3; 11;41;54;61;68) oraz dzieła Tertuliana $O$ duszy (Tert. De anim. II, 3; XXVIII, 1; XXXIII, 1; LIII, 6) i Przeciwko Walentynianom (Tert. Adv. Valent. XV, 1).
} 


\section{WSTĘP}

\section{Augustyn z Hippony}

W Argumentum Ficino najpierw przytoczył autorytet Augustyna, pamiętając lekturę Państwa Bożego i powołując się na następujące trzy fragmenty:

1. Najdłuższą spośród nich jest relacja dotycząca Hermesa Trismegistosa, która znajduje się w Aug. Civ. Dei VIII, 23-27. Tym samym jest ona zbyt rozległa, aby ją w całości zacytować. Warto jednak zwrócić uwagę na te elementy wywodu Augustyna, do których odnosi się Ficino we wstępie do Korpusu:

[...] zdaje się, iż (Hermes) przepowiada ten czas, w którym religia chrześcijańska o ile prawdziwsza i świętsza jest, o tyle silniej i swobodniej wszystkie znosi zmyślone baśnie, aby za łaską najprawdziwszego zbawcy uwolniła człowieka od tych bogów, przez człowieka uczynionych, i aby go oddała Bogu, przez którego człowiek uczynion jest. Lecz Hermes, przepowiadając to, mówi jako przychylny tym bałamuctwom demonów i nie wspomina wyraźnie o imieniu chrześcijan, lecz bolejąc nad tym, co się ma stać, w płaczliwej niejako przepowiedni tak mówi, jak gdyby już zniesione i zburzone zostały te rzeczy, przez zachowanie których utrzymywało się w Egipcie podobieństwo do nieba. [...] Albowiem wiele tam mówi Trismegistos o jednym prawdziwym Bogu, sprawcy świata, wiele takich rzeczy, jakie zawiera prawda, i nie rozumiem, jakim sposobem przez owo zaćmienie serca tak nisko upada, że chce, aby zawsze ludzie poddani byli bogom przez tychże ludzi, jak sam zeznaje, uczynionym; [...] Tych tedy rzeczy zwodniczych, zgubnych, świętokradzkich żałował Hermes Egipcjanin, iż wiedział, że przyjdzie czas, gdy one będą zniesione.

[...] Tenże Hermes, o którym właśnie mówimy, w tej samej książce, gdzie jakoby przyszłość przepowiadając, mówi z płaczem: „Wówczas ziemia ta, stolica kontyn i bożnic, przepełniona będzie mogiłami i nieboszczykami”, świadczy, że bogowie Egiptu byli to zmarli ludzie. [...] A potem jeszcze dalej dodaje: „Hermes, którego imię dziadowe ja mam przebywający w ojczyźnie o jego nazwisku, czyż wszystkich śmiertelników zewsząd przyzywających nie wspiera i nie zachowuje?” Powiada tu autor, iż Hermes starszy, czyli Merkury, którego dziadem swoim zowie, przebywa w Hermopolisie, czyli w mieście o jego nazwisku. Tedy o dwóch bogach mówi, iż ludźmi byli: o Eskulapie i o Merkurym. Co do Eskulapa, to zarówno Grecy, jak i Latynowie to samo twierdzą, ale o Merkurym wielu sądzi, iż nie był śmiertelnikiem, a on go jednak swoim dziadem mieni. No, ale może tamten jest inny Merkury, a ten znów inny, choć jedno imię mają. Ależ bynajmniej o to kopii kruszyć nie myślę: niech sobie tamten będzie inny, a ten znów inny. Ale właśnie i ten, podobnie jak Eskulap, z człowieka bogiem zostaje według świadectwa tak poważnego u nich męża, jakim jest ten właśnie Trismegistos, wnuk tegoż Hermesa. [...] Okazuje się, iż duch przewrotności, za którego podnietą 
Hermes te rzeczy mówił, przez usta tegoż Hermesa zmuszony był wyznać, że już w owe czasy ziemia ta przepełniona była grobami i nieboszczykami, których za bogów czczono. ${ }^{7}$

Augustyn poruszył też (i odrzucił) - wbrew „platonikowi Apulejuszowi” - doktrynę duchów i demonów, które miałyby mieć wpływ na świat ziemski oraz móc pośredniczyć relacji człowieka z Bogiem. Ominięcie tego zagadnienia było świadomym wyborem Ficina, aby uniknąć kontrowersji względem Kościoła.

2. W Civ. Dei XVIII, 8 Augustyn przytacza historię o czasach, w których żył Mojżesz i współczesny mu Prometeusz. Dalej opowiada:

Nie mamy jednakże wiadomości, jacy byli mądrzy ludzie za jego czasów. O jego (Prometeusza) bracie, Atlasie, powiadają, że był wielkim astrologiem, stąd wzięła źródło bajka o nim, że niebo dźwigał, aczkolwiek jego imieniem nazwano też górę, której wysokość przypominała może w mniemaniu ludu dźwiganie nieba. [...] Powiadają, że też w tych czasach był Merkury, wnuk Atlanta, z córki Mai, o czem głośno rozpowiadają powszechnie znane dzieje. ${ }^{8}$

3. Augustyn wymienia jeszcze Hermesa tylko jako pierwszego greckiego filozofa w Civ. Dei XVIII, 39:

Bo co się tyczy filozofii, która, jak sam twierdzi, uczy ludzi tego, co do szczęścia prowadzi, to prace naukowe nad tą gałęzią wiedzy zaczęły być w tym kraju znane dopiero za Merkuriusza, zwanego Trismegistusem, wprawdzie jeszcze dawno przed mędrcami i filozofami Grecji, ale jednakże już po Abrahamie, Izaaku, Jakóbie i Józefie, a nawet dopiero po Mojżeszu. Bo w czasie gdy Mojżesz na świat przyszedł, istniał ów Atlas, wielki astrolog, brat Prometeusza, a dziadek ze strony Matki Merkurego starszego, którego znów wnukiem był ten Merkury Trisgmegistus 9 .

\section{CYCERON}

Argumentum zawiera także cytat z $O$ naturze bogów Cycerona, na które Ficino powołuje się tak samo, jak uczynili to Laktancjusz i Augustyn przed nim. Chodzi o ustęp Cic. Nat. D. III, 20-25:

Jeden z Merkurych, urodzony z ojca Celusa i matki Dies, był tak pobudliwy, że podobno na widok Prozerpiny zapałał zupełnie bezwstydną żądzą cielesną. Drugi,

\footnotetext{
${ }^{7}$ Tłum. Kubicki 316-326.

${ }^{8}$ Tłum. za Kubickim, z wydania pierwszego (227-228) i drugiego (693).

${ }^{9}$ Tłum. za Kubickim, z wydania pierwszego (288-289) i drugiego (734).
} 
syn Walensa i Foronidy, mieszka pod ziemią i nazywa się także Trofoniuszem. Trzeci, który - jak wieść niesie - miał zrodzić z Penelopą Pana, jest synem trzeciego Jowisza i Mai. Czwarty - to syn Nila; wymawianie jego imienia uważaja Egipcjanie za grzech. Piąty, którego czczą Feneaci, zabił jak mówią Argusa, a uciekłszy z tej przyczyny do Egiptu, nadał Egipcjanom prawa i nauczył ich sztuki pisania. Egipcjanie nazywają go Theyt, przy czym imieniem tym określają także pierwszy miesiąc roku. ${ }^{10}$

\section{LAKTANCJUSZ}

W końcu powołał się także na Laktancjusza, który chętnie i często przytaczał autorytet Hermesa Trismegistosa ${ }^{11}$. Campanelli podaje odwołania do Divinae institutiones Laktancjusza, z których korzystał Ficino (Campanelli XXIX-XXX). Pojawią się one w przypisach do przekładu Argumentum. Również jednak w Epitome V swojego dzieła Epitome divinarum institutionum, które powstało jako streszczenie Divinae institutiones, Laktancjusz wprowadził postać Hermesa:

Hermes, który z powodu cnoty i znajomości wielu sztuk zasłużył sobie na przydomek Trismegistus, a który starożytnością nauki wyprzedził filozofów, którego Egipcjanie czczą jako boga, w nieskończonych pochwałach jednego Boga, wynosząc majestat, nazywa go Panem i Ojcem; twierdzi, że jest bez imienia, gdyż nie potrzebuje własnego imienia, ponieważ sam jest z siebie i przez siebie. W piśmie jego do syna taki jest wstęp: Trudno jest Boga rozumieć, wypowiedzieć zaś niemożliwem nawet temu, komu możliwem jest rozumieć; doskonały bowiem nie może być pojętym przez niedoskonałego, ani niewidzialny przez widzialnego ${ }^{12}$.

Następna wzmianka o Hermesie pojawia się w Epitomie XIV, gdzie podano, że „Hermes jest autorem”, wraz z następującą ciekawostką:

Trysmegistus twierdząc, że bardzo mało było mężów, odznaczających się doskonałą nauką, wylicza wśród nich krewnych swoich: Uranusa, Saturna i Merkurego ${ }^{13}$.

Nieco później w tym samym wywodzie, kiedy Laktancjusz przystępuje do definiowania mądrości religijnej, ponownie przytoczył nauki Hermesa w Epitome XLI:

\footnotetext{
${ }^{10}$ Tłum. Kornatowski 197.

${ }^{11}$ Zwięzłe omówienie hermetycznych źródeł wiedzy Laktancjusza można znaleźć w przypisach do odpowiednich fragmentów w niemieckim wydaniu $O$ gniewie Bożym (Laktanz 94-95).

12 Tłum. Czuj 84.

13 Tłum. Czuj 91.
} 
On (syn boga) jest mocą, on rozumem, on mową Boga, on mądrością. Za jego pośrednictwem, jak mówi Hermes, i za jego radą, jak mówi Sybilla, powołał do bytu przewspaniałą i przedziwną budowę tego świata. [..] Wreszcie Platon o pierwszym i drugim Bogu całkiem nie jak filozof, lecz jak wieszczek mówił, idąc prawdopodobnie $\mathrm{w}$ tem za Trysmegistem, którego przytaczam słowa, przełożone z greckiego: „Pan i Stwórca wszechświata, którego nazywamy Bogiem, stworzył drugiego Boga widzialnego i dostępnego zmysłom. Nazywam go dostępnym zmysłom, nie by sam przybierał zmysły, ale że działa na uczucie i wzrok. Gdy więc tego stworzył pierwszego, jedynego, jednego, wydał mu się najlepszym i napełnionym wszelakiem dobrem." [...] Jego imię nikomu nie jest znane, jak tylko jemu i Ojcu, jak uczy Jan w Objawieniu. Hermes twierdzi, że imienia jego nie mogą wymówić śmiertelne usta.

$\mathrm{Na}$ zakończenie znów wspomniał Hermesa Trismegistosa w ostatniej, podsumowującej Epitome LXXIII:

Wobec tego, że wszystko jest prawdziwe i pewne, zgodnemi głosami wszystkich proroków przepowiedziane; gdy to samo opiewał Trysmegistus, to samo Histaspus i Sybilla, nie można wątpić, że nadzieja wszelkiego życia i zbawienia polega tylko na religji Boga ${ }^{14}$.

To ostatnie zdanie zapewne było powodem, dla którego Ficino przekazał Kosmie, że Laktancjusz nie wahał się wymieniać Hermesa wraz z gronem proroków i Sybill; w istocie jednak Laktancjusz nie wyraża tego tak dobitnie jak Ficino, wręcz przeciwnie - porównuje Hermesa do proroków, ale wprost go prorokiem nie nazywa. W parafrazie Ficina tego rodzaju wypowiedzi Laktancjusza można dostrzec, że karmi on poniekąd olbrzymie zainteresowanie swojego zleceniodawcy postacią Hermesa Trismegistosa i nauk. Stanie się to najbardziej odczuwalne w tekście Argumentum, gdy w tym samym akapicie, poprzedzając zestawienie Hermesa z prorokami i Sybillą, czytamy o pismach Hermesa: „Boże nieśmiertelny! Jakże tajemne misteria, jakże zadziwiające zostały objawione wyrocznie!”.

W O gniewie Boga Laktancjusz jeszcze raz wspomina Hermesa, tym razem odsyłając do Cycerona jako swego źródła:

Jeden zatem jest przełożony, Bóg, początek rzeczy, jak myśli i uczy Platon w Tymeusie, wykazując tak wielki jego majestat, iż ani go myśl objąć, ani język wypowiedzieć nie zdoła. To samo poświadcza Hermes, który według Cycerona uważany jest u Egipcjan za boga, mianowicie ten, który dla swego męstwa i znajomości wielu sztuk nazwany został Trysmegistus, a żył o wiele wcześniej

\footnotetext{
${ }^{14}$ Tłum. Czuj 158.
} 
od nie tylko przed Platonem, ale także przed Pytagorasem i owymi siedmiu mędrcami ${ }^{15}$.

\section{Klemens Aleksandryjski a Platon}

Wszystkie te przywołania kościelnych autorytetów, takich jak Augustyn i Laktancjusz, stanowią dość oczywisty wysiłek Ficina, aby pogodzić naukę Hermesa Trismegistosa (oraz tę o nim) z doktryną chrześcijańską, tak aby Kościół katolicki nie mógł zarzucić mu herezji. Zapewne $\mathrm{z}$ tego powodu Ficino chętnie umieszcza Hermesa za czasów Mojżesza i powołuje się na Cycerońskie racjonalizacje, według których Hermes był po prostu człowiekiem. Tak czy inaczej źródła wiedzy o Hermesie dostępne Ficinowi były niejednoznaczne; pisząc wstęp do tłumaczenia Korpusu, postanowił więc pogodzić owe źródła, jednocześnie zabezpieczając się przed niezgodnościami z doktryną chrześcijańską. Być może dlatego również wolał pominąć wzmiankę Klemensa Aleksandryjskiego o Hermesie, ponieważ ten przedstawiał Hermesa jako bóstwo, które Egipcjanie czcili bojaźliwie, przestrzegając wymagających i bardzo precyzyjnych zasad jego kultu. W swym czwartym Kobiercu (VI, 35, 2-37, 3) Klemens opisał tę cześć tak:

(...) Egipcjanie mianowicie uprawiają właściwą sobie filozofię. Na to najbardziej wskazuje ich świętobliwa i dostojna obrzędowość. (...) Według tradycji ustnej, obowiązuje go [śpiewaka kultowego - przyp. M.J.] pamięciowe opanowanie dwu spośród wszystkich ksiąg o Hermesie. Z tych jedna zawiera hymny ku czci bogów, druga zaś spisy żywotów królewskich. (...) Tego [astrologa, występującego po śpiewaku - przyp. M.J.] obowiązuje stała gotowość do recytowania z pamięci tych spośród ksiąg Hermesa, które się odnoszą do astrologii, a jest ich cztery. Pierwsza z nich opisuje układ gwiazd stale świecących, druga - drogę Słońca i Księżyca oraz pięciu planet, trzecia - spotkania i fazy świetlne Słońca i Księżyca, ostatnia resztę dotyczącą czasu wschodu różnych ciał niebieskich. Z kolei wychodzi uczony w świętym piśmie, mający skrzydła na głowie, w ręku księgę i kosz ofiarny, w którym znajduje się czarna farba i trzcina do pisania. Jego powinnością jest znać tak zwane hieroglificzne księgi na temat kosmografii, geografii, drogi Słońca i Księżyca, i pięciu planet, zawierające opis ziemi egipskiej i opis biegu Nilu, opis architektury świątyń i obszarów nadanych świątyniom oraz omawiające miary i niezbędnych sprzęt ofiarniczy. Po wyżej wymienionych idzie z kolei opiekun świętych szat, trzymając łokieć, jako miarę sprawiedliwości, i naczynie ofiarne. Ten zna wszystkie księgi dotyczące wychowania i pieczętowania zwierząt ofiarnych. Dziesięć ksiąg odnoszących się do czci bogów miejscowych i zawierających całą wiedzę w zakresie obrzędów egipskich, jak na przykład ofiar w ogóle, ofiar

\footnotetext{
${ }^{15}$ Tłum. Czuj 183.
} 
z pierwocin, owoców, hymnów, modlitw, procesji, świąt i tym podobnych. Wreszcie po tych wszystkich wychodzi profeta (...). Sam profeta, jako zwierzchnik świątyni, zna na pamięć dziesięć tak zwanych hieratycznych ksiąg. (...) A więc czterdzieści dwie księgi są niezbędne dla kultu Hermesa. Spośród nich trzydzieści sześć zawiera cała filozofię egipską i tych uczą się na pamięć wyżej wymienieni kapłani. Pozostałe zaś, w liczbie sześciu, opanowują pamięciowo pastoforowie [,noszący kapliczki” - przyp. M.J..]. ${ }^{16}$

Dla Ficina ta relacja Klemensa mogła się kłócić ze znanymi mu poglądami Platona, wszak to Ateńczyk był uwieńczeniem „prateologii” (prisca teologia), a nie Aleksandryjczyk ${ }^{17}$. Platon dwukrotnie bowiem przytoczył opowieść o Theucie, który darował Egipcjanom pismo: raz w Fajdrosie $(274 \mathrm{c}-\mathrm{e})^{18}$, raz w Filebie $(18 \mathrm{~b}-\mathrm{d})^{19}$, gdzie boskość Tota zostaje podana w wątpliwość. Jako platonik oczywiście odniósł te passusy do epizodu w Polityku (290d-e), z którego pochodzi wzmianka o królach elekcyjnych w Egipcie; Ficino tę przypowieść Platona, mającą usprawiedliwić jego doktrynę króla-filozofa, zastosował do Hermesa Trismegistosa w wierszach 22-30 objaśnień dla Kosmy Medyceusza. Mowa tutaj o następującej wypowiedzi w Polityku:

[P]odstawa kapłanów i wieszczków tchnie rzeczywiście dumą i zyskuje sobie opinie poważną ze względu na doniosłość ich funkcji. Tak że w Egipcie nawet nie wolno królowi panować, jeżeli nie posiada wiedzy kapłańskiej. A jeżeli się nawet kiedyś król z innego stanu gwałtem na tron narzuci, to musi być później wtajemniczony i wpisany do stanu kapłańskiego. ${ }^{20}$

\footnotetext{
${ }^{16}$ Tłum. Niemirska-Pliszczyńska 131-132.

${ }^{17}$ Dobry wstęp do tej koncepcji można znaleźć w Trzycińska 92-98.

${ }^{18}$ Pl. Phdr. 274c-274e: „(...) Sokrates: Słyszałem więc, że koło Naukratis, w ziemi egipskiej, miał siedlisko jeden z prastarych bogów w tych strona. Do niego należy święty ptak, którego zowią Ibisem. Sam bożyc nosi imię Theut. Ów odkrył przódy liczbę i rachunek, geometrię i astronomię, a na dodatek gry w rzutki i kostki, i nade wszystko znaki pisma. Nad całym Egiptem królował wtedy Thamus, z siedziby koło wielkiego grodu w górnej połaci kraju. Hellenowie nazywają gród Egipskimi Tebami, a boga - Ammonem. Theut podszedł do niego, przedstawił swoje sztuki i rzekł, że trzeba je przekazać innym Egipcjanom. [...] Theuth rzekł: „Ta nauka, królu, czyni z Egipcjan ludzi mądrych i pomnych w stopniu wyższym niż dotąd. Odkryłem lek na mądrość i pamięć". Tłum. Zwolski 161-162.

${ }^{19}$ Pl. Phlb. 18b-18c: ,[...] Sokrates: Kiedy bezkresny głos przejrzał myślą czy bóg pewien czy nawet boski człowiek - opowieść powiada, że nim stał się w Egipcie pewien Theuth, który w pierwszym odkrycie dojrzał myślą w bezkresie dźwięki głośne [= samogłoski] (...). Dojrzawszy zaś, że nikt z nas jednego samego przez się bez ich wszystkich [innych głosek przyp. M.J.] by nie rozumiał, i drogą rozumu dochodząc, że więź ta jest jedna i je wszystkie w pewien sposób jednym czyni, jako jedną sztukę, która do nich się odnosi mianem sztuki piśmienniczej określając przezwał”. Tłum. Zwolski 18-19.

${ }^{20}$ Witwicki 118 .
} 
Zdaje się, że właśnie Klemens Aleksandryjski mógł zwrócić uwagę Ficina na zgodność Platona z historycznością Hermesa, gdy stwierdził w pierwszym Kobiercu (I, 68, 3):

[Platon] w Fajdrosie ukazuje nam króla egipskiego mądrzejszego nawet od Tota, o którym wiedział, że był utożsamiany z Hermesem. ${ }^{21}$

Intencję zespolenia Korpusu $\mathrm{z}$ teologią chrześcijańską można odnaleźć też w skonstruowanej przez Ficina koncepcji prateologii, w której strażnikami boskiej wiedzy i prorokami chrześcijańskimi czyni postacie mityczne oraz starożytnych filozofów w pewnej ścisłej kolejności - jak o tym pisze „exordium sumens a Mercurio, a divino Platone penitus absoluta”. W tym zdaniu nawiązuje on zresztą do starej tradycji, która czciła Platona jako boga (niemniej jest on tutaj w bezpieczny dla Ficina sposób przedstawiony jako teolog chrześcijański).

\section{PRZEKŁAD ARGUMENTUM - \\ SŁOWA WSTĘPNEGO DO DZIEŁA MERKUREGO TRISMEGISTOSA}

\section{MARSILIO FICINO Z FLORENCJI DO KOSMY MEDYCEUSZA, OJCA OJCZYZNY}

W czasie, w którym urodził się Mojżesz, działał astrolog Atlas, brat fizyka Prometeusza i dziadek Merkurego ze strony matki, którego bratankiem był Merkury Trismegistos. Tak zaś pisze o nim święty Augustyn ${ }^{22}$, chociaż Cyceron $^{23}$ i Laktancjusz ${ }^{24}$ sądzą raczej, że było pięciu z rzędu Merkurych, a piątym był ten, którego Egipcjanie nazywali Them ${ }^{25}$, Grecy zaś Trismegistos. Twierdzą oni, że ten oto Merkury zabił Argosa, stanął na czele Egipcjan oraz ustanowił dla nich prawa i pismo, a postaci liter wprowadził w kształtach zwierząt i drzew. Ludzie otaczali go tak wielką czcią, że został zaliczony w poczet bogów; wybudowano dużą liczbę świątyń jego bóstwa; jego prawdziwego imienia ze względu na bojaźń nie wolno było wymawiać

\footnotetext{
${ }^{21}$ Tłum. Niemirska-Pliszczyńska 50.

${ }^{22}$ August. Civ. Dei XVIII, 39.

${ }^{23}$ Cic. Nat. D. III, 20-25 (56).

${ }^{24}$ Lactant. Div. inst. I, 6,2-4.

${ }^{25}$ Według komentarza Maurizia Campanellego jest to skrót od Thempnugma (Campanelli 3; por. także Campanelli XXXIII-XXXV); czyli odmienione Theyt, egipski bóg Tot, jak w Cic. Nat. D. III, 20-25.
} 
powszechnie ani lekkomyślnie; pierwszy miesiąc roku u Egipcjan nosił nazwę od jego imienia; miasto, które założył, po dziś dzień jest zwane po grecku Hermopolis ${ }^{26}$, czyli miastem Merkurego. ${ }^{27}$ Nadali mu zaś miano Trismegistos, czyli Trzykroćwielki, ponieważ był największym filozofem, największym kapłanem i największym władcą wszech czasów. U Egipcjan było bowiem zwyczajem - jak już o tym pisał Platon - wybierać spośród grupy filozofów swych kapłanów, spośród grona kapłanów z kolei króla. Ów zatem, jak bystrością i nauką prześcigał wszystkich filozofów, tak potem, gdy został kapłanem, przewyższał wszystkich kapłanów świętością życia i czcią dla bogów, aż wreszcie, otrzymawszy godność królewską, wydawaniem praw i swymi czynami przyćmił sławę poprzednich królów tak, że słusznie został nazwany Trzykroć Wielkim. Jako pierwszy pośród filozofów przeszedł od matematyki i fizyki do rozważań nad sprawami bożymi: jako pierwszy z wielką mądrością rozprawiał o majestacie Boga, o hierarchii demonów i przeobrażeniach dusz - otrzymał więc miano założyciela teologii. Po nim drugie miejsce w starożytnej teologii zajął Orfeusz ${ }^{28}$. Następnie za sprawą Orfeusza w święte nauki został wtajemniczony Aglaofemos ${ }^{29}$, a po Aglaofemosie w teologii nastąpił Pitagoras, którego naśladowcą był Filo$\operatorname{laos}^{30}$, poprzednik naszego boskiego Platona. Tak oto jedna szkoła dawnej teologii, pod każdym względem ze sobą zgodna, zespoliła się w jakimś zadziwiającym porządku z sześciu teologów - początek biorąc od Merkurego, a kończąc się na boskim Platonie.

Merkury napisał zaś bardzo wiele ksiąg odnoszących się do poznania rzeczy boskich, w których - o, Boże nieśmiertelny! - objawione zostały jakże tajemne misteria, jakże zadziwiające wyrocznie! Nie tylko wypowiadał się jako filozof, lecz często jako prorok przepowiadał przyszłość. Przewidział upadek dawnej religii, powstanie nowej wiary, przyjście Chrystusa, mający nadejść Dzień Sądu, zmartwychwstanie ludzi, odnowienie świata oraz chwałę błogosławionych i potępienie grzeszników. Stąd Aureliusz Augustyn ${ }^{31}$ miał wątpli-

\footnotetext{
${ }^{26} \mathrm{O}$ mieście założonym przez Hermesa mówi też Picatrix, tam jednak nosi ono inną nazwę. Por. Yates 54-56.

${ }^{27}$ 13-20: „In tanta.. veneratione fuit ut.. relatus sit; templa.. constructa..; nomen.. pronuntiare.. non licebat; ..nomine eius cognominatus; oppidum ab eo conditum.. Konstrukcja ut cum coniunctivo", w której przy wyliczaniu Ficino po każdym średniku opuszcza $u t$.

${ }^{28}$ Mityczny poeta; mniej więcej od VI wieku p.n.e. uważany za kapłana i twórcę mistycznej sekty orfickiej.

${ }^{29}$ Nauczyciel Pitagorasa, znany z pitagorejskich tekstów pochodzących z okresu hellenistycznego; por. Riedweg 8.

${ }^{30}$ Filolaos z Tarentu; żył na przełomie V i IV wieku p.n.e., pitagorejski filozof i matematyk, współczesny Platonowi.

${ }^{31}$ August. Civ. Dei VIII; XXIII; XXVI.
} 
wości, czy nie głosił on wielu rzeczy dzięki biegłej znajomości gwiazd i na podstawie objawienia demonów. Laktancjusz ${ }^{32}$ zaś nie waha się wyliczyć go pośród Sybilli i proroków.

Spośród wielu ksiąg Merkurego są szczególnie dwie dotyczące spraw boskich: jedna z nich mówi o woli boskiej, druga zaś o potędze i mądrości Boga. Pierwsza została zatytułowana Asklepios, druga Pimander. Tę pierwszą przełożył na łacinę platończyk Apulejusz ${ }^{33}$, ta druga natomiast do naszych czasów zachowała się u Greków. Niedawno jednak, przywieziona z Macedonii do Italii staraniem Leonarda Pistoryjczyka ${ }^{34}$, uczonego i pobożnego mnicha, szczęśliwie dotarła do nas. Ja z kolei, gdy zachęcony przez Ciebie postanowiłem ją przełożyć z greki na łacinę i uznałem, że będzie słuszne, szczęsny Kosmo, abym dziełko to poświęcił Twemu imieniu. Dzięki wszelkiemu Twemu wsparciu i dostarczaniu wielu książek mogłem zwrócić się do studiów autorów greckich, dlatego przystoi, abym przedstawił $\mathrm{Ci}$ pierwsze owoce mych greckich nauk. Zresztą nie godziłoby się, abym dzieło tak mądrego filozofa, tak pobożnego kapłana i tak potężnego władcy dedykować komuś innemu niż temu, kto przewyższa wszystkich pozostałych mądrością, pobożnością i potęgą.

Tytuł tej księgi (że przejdę już do dzieła Merkurego) brzmi Pimander, gdyż spośród czterech osób, które w dialogu ze sobą dyskutują, pierwsze części zostały przypisane Pimandrowi ${ }^{35}$. On zaś napisał księgę pismem Egipcjan, ale opanował również język grecki, przez co - dokonując przekładu - objawił Grekom misteria egipskie. Przedmiotem tego dzieła jest rozprawianie o potędze i mądrości Boga. Ponieważ ich działanie jest dwojakie: pierwsza z nich zawiera się w samej naturze Boga, zaś druga rozciąga się na zewnątrz; pierwsza wprawdzie stwarza pierwotny i wieczny świat, drugą z kolei rodzi wtórny i osadzony w czasie świat; oba działania i oba światy omawia on dogłębnie: czym jest potęga Boga, czym mądrość, w jakiej kolejności one stwarzają to, co wewnętrzne, i jak krok po kroku rodzą to, co zewnętrzne; następnie również, jak powstałe rzeczy się mają względem siebie - w czym się zgadzają, czym się różnią oraz wreszcie, jak się mają wobec swojego Stwórcy.

\footnotetext{
${ }^{32}$ Lactant. Div. inst. II, 8, 48; IV, 6, 3; VII, 18, 3-5; VI, 25, 10.

${ }^{33}$ Rzymski pisarz i filozof z II wieku n.e., thumaczył i komentował m.in. dzieła Platona.

${ }^{34}$ Leonardo z Pistoii, miasta w Toskanii. Istnieje - dość mało prawdopodobna - hipoteza, że mogło tutaj chodzić o Leonarda da Vinci (por. Steiner 9-10). Przyjmuje się, że da Vinci urodził się $\mathrm{w}$ roku 1452, zatem $\mathrm{w}$ roku 1460, kiedy manuskrypty hermetyczne trafiły do Florencji, miałby ok. ośmiu lat.

${ }^{35}$ Postać mityczna, czasami jako Poimandres (gr. pasterz); nazwa pochodzi najprawdopodobniej z języka egipskiego, pierwotnie oznaczała "Mądrość Re”; por. Kingsley 1-24.
} 
Dzieło zostało podzielone na piętnaście ksiąg, przy czym pierwsza część dialogów została przypisana Pimandrowi, druga należy do Trismegistosa, trzecia do Eskulapa ${ }^{36}$, a na czwartym miejscu znalazł się Tat ${ }^{37}$. Z tego wynika, że Merkury zamierzał kształcić Eskulapa i Tata w zakresie spraw boskich. O sprawach boskich nie może nauczać ten, który się ich sam nie nauczył. A my nie możemy pojąć ludzkim rozumem tych rzeczy, które przewyższają naturę ludzką. Dlatego trzeba boskiego światła, tak jak dzięki światłu słonecznemu możemy oglądać samo Słońce. Światło umysłu boskiego nigdy nie wsączy się $\mathrm{w}$ duszę człowieka, jeśli nie zwróci się ona całkowicie ku umysłowi Boga, jak Księżyc w stronę Słońca ${ }^{38}$. Dusza nie zwróci się ku umysłowi ${ }^{39}$, jeśli sama nie stanie się umysłem. A stanie się umysłem nie wcześniej, niż gdy porzuci złudzenia zmysłów i mgły fantazji. $Z$ tego też powodu nasz Merkury wyzuwa się z ciemności zmysłów i fantazji; znów otwiera się na wejście umysłu; wnet Pimander, czyli boski umysł, weń wpływa ${ }^{40}$, dzięki czemu następnie zostaje rozważony porządek wszystkich rzeczy - zarówno tych istniejących w Bogu, jak i tych od Boga promieniujących. W końcu pozostałym ludziom wyjaśnia też te rzeczy, które przez boskie światło zostają objawione.

Oto więc tytuł, przedmiot i układ dzieła. Ty zaś, szczęsny Kosmo, czytaj szczęśliwie i żyj długo, aby i ojczyzna długo miała się dobrze.

\section{BIBLIOGRAFIA}

Apulejusz z Madaury. O bogu Sokratesa, O Platonie i jego nauce, O świecie, oraz PseudoApulejusz, Asklepiusz, czyli rozmowa z Hermesem Trismegistosem. Tłum. Kazimierz Pawłowski, Wydawnictwo Naukowe PWN, 2002.

Augustyn, święty. Państwo Boże. Tłum. Władysław Kubicki, ANTYK, 1998.

\footnotetext{
${ }^{36}$ Grecki bóg lecznictwa, nazywany także Asklepiosem; czczony również w Egipcie.

${ }^{37}$ Prawdopodobnie Tatios; mogłoby też chodzić o egipskiego boga Tota.

38 95-96: „nisi ipsa, ceu luna solem, ad dei mentem penitus convertatur”. Czasownik convertere $\mathrm{w}$ kontekście hermetycznym może mieć ambiwalentne znaczenie - „zmieniać, przekształcać się” bądź „Zwracać się ku czemuś” - gdyż według nauk hermetyzmu ruch planet ciał niebieskich odgrywa ważną rolę, oddziaływając również na życie człowieka.

${ }^{39} \mathrm{Tj}$. umysłowi Boga.

40 95-101: „infunditur anime.. in adytum mentis.. in hunc influit..”. Gra słów, polegająca na porównaniu boskiego umysłu (divina mens) do cieczy, która może zapełnić (infundire) duszę i wpłynąć (influere) do ludzkiego rozumu. Dostęp (adytum), czyli wejście; semantycznie w tym przypadku może lepiej: dopływ albo wlot. W przekładzie ta gra słów nie została oddana. Por. Voeglin 109; Voegelin skupia się na świetlnym charakterze opisywanej przez Ficina idei. Nie bezpodstawnie, jak mniemam, gdyż światło również może coś „zalać” swoimi promieniami. Tak przynajmniej sugerowałyby terminy niem. Flutlicht i ang. floodlight.
} 
Bugaj, Roman. Hermetyzm. Ossolineum, 1991.

Campanelli, Maurizio. „Marsilio Ficino’s portrait of Hermes Trismegistus and its afterlife”. Intellectual History Review, t. 29, $\mathrm{nr}$ 1, 2019, ss. 53-71.

Campanelli, Maurizio. Mercurii Trismegisti Pimander sive de potestate et sapientia Dei a cura di Maurizio Campanelli. Aragno, 2011.

Cicero, Marcus Tullius. Pisma Filozoficzne, t. 1. Tłum. Witold Kornatowski, Państwowe Wydawnictwo Naukowe, 1960.

Czerkawski, Jan. „Hermetyzm w Polsce w XVI wieku”. Roczniki Filozoficzne, t. 37-38, nr 1, 1989-1990, ss. 153-169.

Das Corpus Hermeticum durch Marsilius Ficinus aus dem Griechischen ins Lateinische und jetzt aus dessen Latein auf jeweils gegenüberliegender Seite ins Deutsche übertragen durch M.P. Steiner. Edition Oriflamme, 2014.

Ebeling, Florian. In The Secret History of Hermes Trismegistus: Hermeticism from Ancient to Modern Times. Tłum. David Lorton, Cornell University Press, 2007.

Howlett, Sophia. Marsilio Ficino and His World. Palgrave Macmillan, 2016.

Kingsley, Peter. „Poimandres: The Etymology of the Name and the Origins of the Hermetica”. Journal of the Warburg and Courtauld Institutes, t. 56, 1993, ss. 1-24.

Klemens Aleksandyjski. Kobierce. Tłum. Janina Niemirska-Pliszczyńska, t. 2, Instytut Wydawniczy Pax, 1994.

Laktancjusz. Pisma wybrane. De mortibus persecutorum - Epitome - De ira Dei. Tłum. Jan Czuj, Jan Jachowski Księgarnia Uniwersytecka, 1993.

Laktanz. Vom Zorne Gottes. Tłum. Heinrich Kraft i Antonie Wlosok, Wissenschaftliche Buchgesellschaft 1983.

MacDonald, Paul S. Nature Loves to Hide: An Alternative History of Philosophy. Alternative Books, 2018.

Myszor, Wincenty. „Corpus Hermeticum IV. Wstęp, przekład z greckiego, komentarz”. Studia Theologica Varsaviensia, t. 16, nr 1, 1978, ss. 186-196.

Myszor, Wincenty. „Corpus Hermeticum VI i VII. Wstęp, przekład z greckiego, komentarz”. Studia Theologica Varsaviensia, t. 16, nr 2, 1978, ss. 241-247.

Myszor, Wincenty. „Corpus Hermeticum XIII. Wstęp, przekład z greckiego, komentarz”. Studia Theologica Varsaviensia, t. 17, nr 1, 1979, ss. 245-256.

Myszor, Wincenty. „Poimandres. Wstęp, przekład, komentarz”. Studia Theologica Varsaviensia, t. 15 , nr 1, 1977, ss. 205-216.

Nawrot, Liliana. „Źródła hermetyzmu i alchemii”. Nowa Krytyka, t. 10, 1999, ss. 179-199.

Platon. Phaidros. Tłum. Edward Zwolski, Aureus 1996.

Platon. Phileb, Tłum. Edward Zwolski, Aureus, 1999.

Platon. Sofista. Polityk. Tłum. Władysław Witwicki, ANTYK, 2002.

Ptaszek, Robert T., Diana Sobieraj, redaktorzy. Ezoteryczne tropy w kulturze Europy. Wydawnictwo KUL, 2013.

Riedweg, Christoph. Pythagoras. His Life, Teaching, and Influence. Tłum. Steven Rendall, Cornell University Press, 2005.

Sowińska, Agata. Hermetica średniowiecza i renesansu. Wydawnictwo Uniwersytetu Śląskiego, 2018.

Sytnik-Czetwertyński, Janusz. „Hermetyzm w filozofii Isaaca Newtona”. Kwartalnik Filozoficzny, t. 43, nr 2, 2015, ss. 151-167. 
Śnieżyńska-Stolot, Ewa. „'Nereidy i morskie stwory’ w Kaplicy Zygmuntowskiej na Wawelu. Na marginesie książki Stanisława Mossakowskiego: Kaplica Zygmuntowska (1515-1533). Problematyka artystyczna i ideowa mauzoleum króla Zygmunta I. Warszawa 2007 Instytut Sztuki Polskiej Akademii Nauk". Kwartalnik Historii Nauki i Techniki, t. 54, nr 3-4, 2009, ss. 275-287.

Śnieżyńska-Stolot, Ewa. Picatrix Latinus. Ikonografia planet i planet dekanicznych $w$ rękopisie krakowskim. Wydawnictwo Uniwersytetu Jagiellońskiego, 2009.

Trzcińska, Izabela. Mit, logos i ratio. Wybrane koncepcje racjonalności od XV do XVII wieku. Wydawnictwo Uniwersytetu Jagiellońskiego, 2011.

Yates, Frances A. Giordano Bruno and the Hermetic Tradition. The University of Chicago Press, 1964.

Zieliński, Tadeusz. Hermes Trzykroć Wielki. Zygmunt Pomarański i Spółka, 1921.

\section{HERMES TRISMEGISTOS WEDŁUG MARSILIA FICINA. ARGUMENTUM - PRZEKŁAD I KOMENTARZ}

\section{Streszczenie}

Tak zwany Korpus Hermetyczny doczekał się już wielu przekładów, między innymi na język polski, choć polskie przekłady powstawały głównie na podstawie wcześniejszych tłumaczeń na inne języki nowożytne, którym pośredniczyła wersja łacińska. Długą tradycję przekładów tego filozoficzno-mistyczno-ezoterycznego dzieła zapoczątkował Marsilio Ficino w 1463 r., dokonując tłumaczenia z greki na łacinę. Łacińska wersja Korpusu do 1585 r. doczekała się aż szesnastu edycji. Nie wszystkie wydania uwzględniały również wstęp, którym Ficino opatrzył swój przekład. W owym wstępie Ficino odwołuje się do znanej mu tradycji o boskim mędrcu-proroku zarówno antycznej, jak i wczesnochrześcijańskiej. W niniejszej pracy Ficinowski wstęp do Korpusu Hermetycznego został opatrzony własnym komentarzem wstępnym, który daje polskiemu czytelnikowi możliwość zapoznania się z ówczesnym stanem wiedzy na temat Hermesa Trismegistosa oraz interpretacją tejże wiedzy. Następnie zaprezentowane zostaje nowe polskie tłumaczenie oryginalnego wstępu Ficina, w którym tenże streścił dla swego zleceniodawcy, Kosmy Medyceusza, dostępne mu informacje o Hermesie Trismegistosie, a jednocześnie ukierunkował chrześcijańską recepcję antycznego hermetyzmu od renesansu aż do oświecenia.

Słowa kluczowe: Korpus Hermetyczny; Marsilio Ficino; Hermes Trismegistos; Augustyn; Laktancjusz; Klemens Aleksandryjski.

\section{HERMES TRISMEGISTUS ACCORDING TO MARSILIO FICINO: ARGUMENTUM - TRANSLATION AND COMMENTARY}

\section{S u m m a ry}

The so-called Corpus Hermeticum has had a long history of translations, initiated by Marsilio Ficino's Latin version of the Greek original he prepared in 1463. So far Polish translations of the entire text remain rather less precise due to the fact that they are third-degree translations mediated by translations into other modern languages from the Latin version. Ficino's Latin translation had an introduction, in which he laid out both the ancient and early Christian tradition regarding Hermes Trismegistus. The presented article provides a commentary to Ficino's introduction and gives the Polish audience an opportunity to have all pieces of information that Ficino 
had access to in order to understand the knowledge of the time. Further, this paper presents the new Polish translation of Ficino's introduction.

Key words: Corpus Hermeticum; Marsilio Ficino; Hermes Trismegistus; Augustine; Lactantius; Clement of Alexandria. 